\section{СЕЛЕКТИВНОЕ ЛАЗЕРНОЕ}

\section{ПЛАВЛЕНИЕ:}

\section{ПРИМЕНЕНИЕ И ОСОБЕННОСТИ} ФОРМИРОВАНИЯ ТРЕХМЕРНЫХ КОНСТРУКТИВНЫХ ТЕХНОЛОГИЧЕСКИХ

\section{ЭЛЕМЕНТОВ}

\author{
М.А. Мельникова, к.т.н., Д.С. Колчанов, \\ "Центр аддитивных технологий", \\ Д.М. Мельников, к.т.н., \\ каф. МТ-12, МГТУ им. Н.Э. Баумана, Москва
}

Использование технологии селективного лазерного плавления в различных областях медицинской техники и машиностроения позволяет перейти от технологий быстрого прототипирования к непосредственному выращиваю готовых изделий, требующему минимальной послеоперационной обработки. В статье представлен ряд наработок в области SLMтехнологии (в том числе особенности выращивая подпорок, необходимых для успешного получения сплошных изделий), выполненных в МГТУ им. Н.Э. Баумана с целью ускорения их передачи в индустриальное производство.

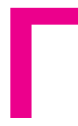

руппа аддитивных технологий, или технологий быстрого прототипирования, является одной из наиболее интенсивно развивающихся отраслей современного машиностроения В эту группу, в числе прочих, входят методы селективного лазерного спекания и плавления. Селективное лазерное плавление (СЛП) находится среди наиболее важных методов, так как позволяет получать практически готовые изделия путем сплавления металлических порошков. Особенность применения данной технологии связана, как правило, с изготовлением изделий сложной геометрии, либо из материалов, плохо поддающихся механической обработке.

СЛП является одним из способов, который позволяет выращивать детали из различных металлических порошков, слой за слоем, фор мируя уникальную конфигурацию изделия путем локального воздействия лазерного излуче-
SELECTIVE LASER MELTING: APPLICATION AND FEATURES OF THREE-DIMENSIONAL STRUCTURAL ENGINEERING ELEMENTS FORMATION

\author{
M.A. Melnikova, PhD in Technological Sciences, \\ D.S. Kolchanov, \\ "Center of the additive technologies", \\ D.M. Melnikov, PhD in Technological Sciences, MT-12, \\ Bauman Moscow State Technical University, Moscow
}

The use of selective laser melting technology in various areas of medical equipment and mechanical engineering allows passing from rapid prototyping technique to immediate grow of finished products, demanding minimum after operating processing. A number of exploratory works in the field of selective laser melting technology (including features of supporting piece growing necessary for successful continuous products receiving) executed in Bauman Moscow State Technical University for the purpose of acceleration of their transfer to industrial production is presented in article.

$\mathrm{T}$ he group of the additive technologies or rapid prototyping techniques is one of the most intensively developing branches of the modern mechanical engineering. Methods of selective laser sintering and melting are included among other in this group. The selective laser melting is among the most important fields as it allows receiving practically finished products by sintering of metal powders. The feature of this technology usage is bound, as a rule, to manufacture of composite geometry products, or products from materials badly machinable.

The selective laser melting is one of methods allowing growing details from various metal powders, layer by layer forming a unique configuration of a product by local impact of a laser radiation on powder with remelting of each layer. For each type of powder differing by the size and form of fraction, chemical composition there are particular features at cultivation, however the common principle is identical for all types. The main feature of selective laser melting is a possibility of irregular shapes parts creation, including those with internal channels and cavities [1] having the given mechanical and physical 
ния на порошок с переплавлением каждого слоя. Для каждого типа порошка, отличающегося размером, формой фракции и химическим составом, существуют свои особенности при выращивании, однако общий принцип одинаков для всех. Основная черта СЛП - возможность создания деталей сложных форм, в том числе с внутренними каналами и полостями [1] с заданными механическими и физическими свойствами. Технология постепенно внедряется в аэрокосмическую и автомобильную отрасли, инструментальное производство сложных деталей и прочие области, где она в скором времени найдет широкое применение [2]. СЛП уже активно используется в ювелирной промышленности и медицине (биомедицинские зубные протезы, коронки и прочее рис.1, [3, 4]).

Различные проблемы, возникающие при разработке технологии сЛП, требуют глубокой проработки на разных уровнях: теоретическом построения подробной модели процесса, и практическом - проведения экспериментальных исследований по выбору оптимальных параметров для выращивания изделий из определенных порошков. Сложность экспериментальных исследований заключается в постановке многофакторного эксперимента для понимания процесса формирования как отдельных зон сплавления, так и изделия в целом, и последующего исключения таких негативных эффектов, как сфероидизация расплавленных порошинок, пористость, термическая деформация, трещины, и т.д. [5].

Одним из наиболее сложных, но важных этапов при выращивании деталей является создание подпорок, которые удерживают выступающие и нависающие части детали при изготовлении. Особенность этих элементов определяется мелкой периодической структурой и миниатюрными элементами при переплавлении слоев. Необходимо отметить, что на сегодняшний день полые сетчатые изделия сравнительно легко получаются методом СлП, но выращивание деталей со 100\%ной плотностью пока затруднено. Одна из составляющих этой проблемы - получение оптимальной структуры подпорок, которая бы гарантировала возможность выращивания плотного изделия и его последующее отделение от подпорок.

На кафедре МТ-12 МГТу им.Н.Э.Баумана активно разрабатываются лазерные аддитивные установки и технологии, в том числе для слП. Недавно разработанный комплекс (рис.2) позволяет проводить эффективные исследования различных аспектов этой технологии. Комплекс

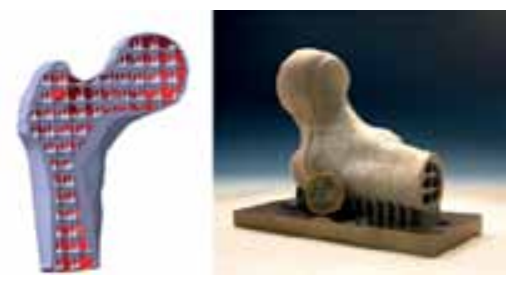

Puс.1. Модель искусственной кости, полученная методом СЛП [4]

Fig. 1. Artificial bone model made by selective laser melting method [4]

properties. This technology gradually penetrates into space and automobile branches, instrumental production of composite parts and other fields where it will shortly become widely used [2]. Selective laser melting is already widely used in the jewellery industry and medicine (biomedical dentures, cutter heads and other-Fig.1, [3, 4]).

Various problems arising when developing selective laser melting technology demand deep study at the following different levels: theoretical, i.e. creation of detailed process model, and practical, i.e. conducting the experimental research at the choice of optimum parameters for cultivation of products from particular powders. The complexity of the experimental research

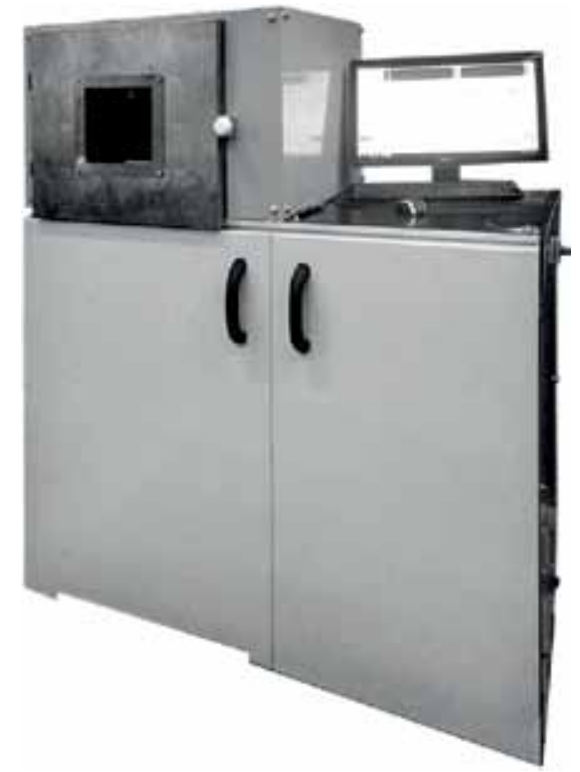

Puc.2. Установка "СЛП-110", произведенная в МГТУ им. Н.Э. Баумана

Fig. 2. SLM-170 installation made in Bauman Moscow State Technical University 
удовлетворяет предъявляемым современной индустрией требованиям и не уступает западным аналогам.

Принципиальная схема процесса слП показана на рис.3. Герметичная камера, заполненная инертным газом с возможностью нагрева атмосферы, включает в себя платформу выращивания, которая имеет вертикальную систему перемещения, а также два бункера для порошка. Из бункера-питателя путем вертикального перемещения платформы порошок подается на поверхность рабочего стола. С помощью ножа или ролика необходимый объем порошка переносится к плат форме для выращивания и укладывается на нее ровным слоем заданной толщины. Лишний порошок ссыпается во второй бункер. Далее происходит воздействие лазерного излучения на порошок, его сплавление на первом этапе с подложкой, а далее с предыдущим выращенным слоем. Как только слой выращен, платформа выращивания с деталью опускается вниз, а процесс создания нового слоя повторяется по той же схеме.

При построении модели экспериментальных исследований и выбора оптимальных условий проведения сЛП очень важно учитывать отработку повторяемости процесса с заданной точностью [8]. Все варьируемые параметры процесса сЛП можно разделить на три основные группы $[6,7]$ :

- зависящие от характеристик порошка,

- зависящие от характеристик лазерного излучения,

- зависящие от стратегии сканирования.

Акцент необходимо сделать на обеспечении повторяемости при выращивании изделий с миниатюрной геометрией. Обеспечить повто ряемость можно правильным выбором режимов и аккуратным построением подпорок, что гарантирует отсутствие искажений очередного слоя, которые могут накапливаться и приводить к серьезным дефектам при большом количестве слоев.

Исследования оптимального выращива ния подпорок мы проводили на нержавеющей стали. В силу высокой степени сплавляемости и благодаря широкому распространению в промышленности для исследования выбран поро шок нержавеющей стали 316L. Ее аналогами явля ются нержавеющие стали 1,4429 и 03X17Н14M3. Состав порошка приведен в таблице (порошок однородный сферический), морфология его показана ни рис.4. На рис.5 представлен химический состав порошка после проведения рентгенов

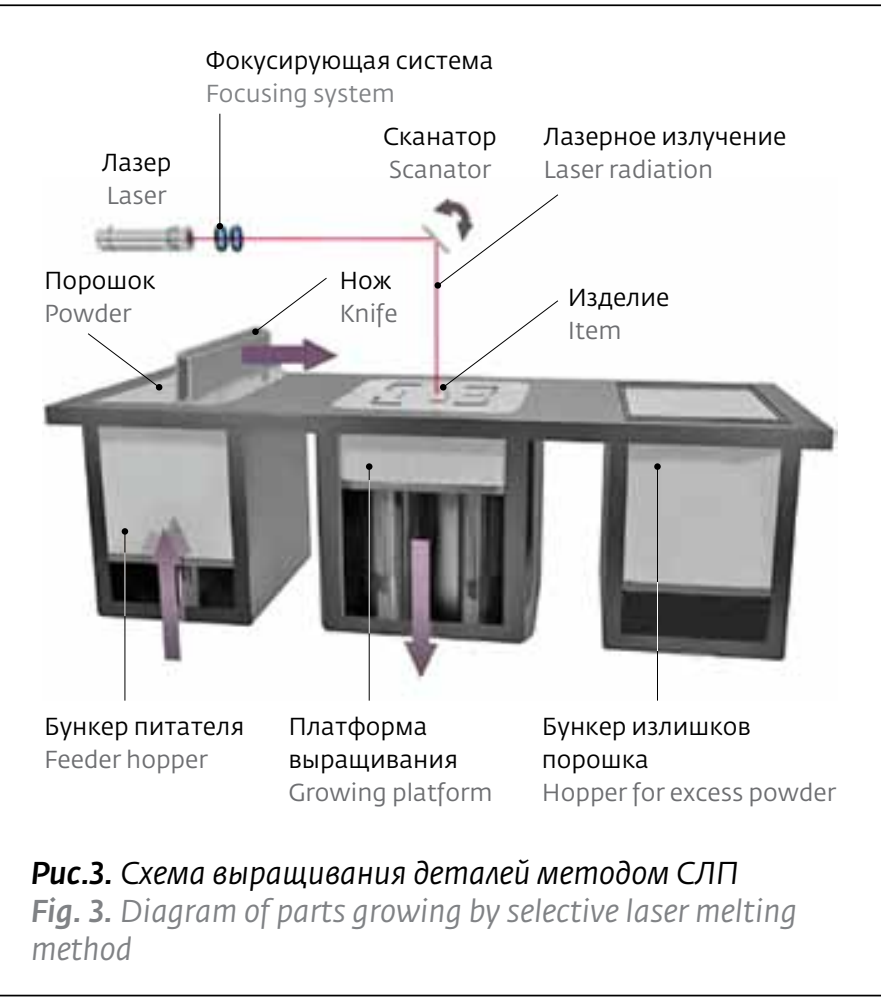

consists in multifactorial experiment statement for comprehension of formation process both of separate fusion zones, and a product in general, and the subsequent exception of such negative effects as spheroidizing of melted grains of powder, porosity, thermal deformation, cracks, etc. [5].

One of the most complex but important stages at parts growing is a creation of supporting piece which holds the acting and hanging elements of a part at manufacture. The feature of these elements is defined

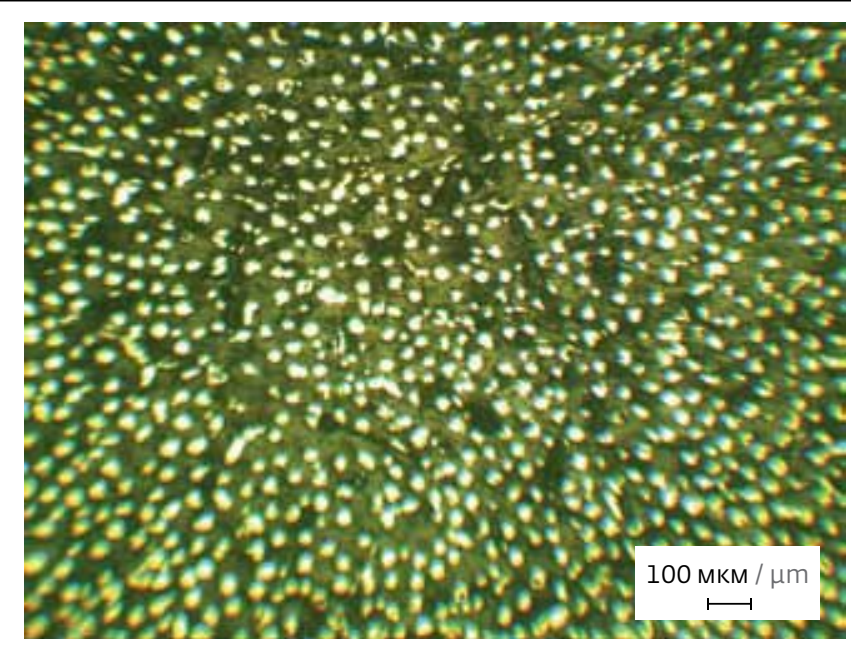

Puc.4. Морфология частиц порошка стали $316 \mathrm{~L}$ Fig. 4. Morphology of steel powder particles $316 \mathrm{~L}$ 


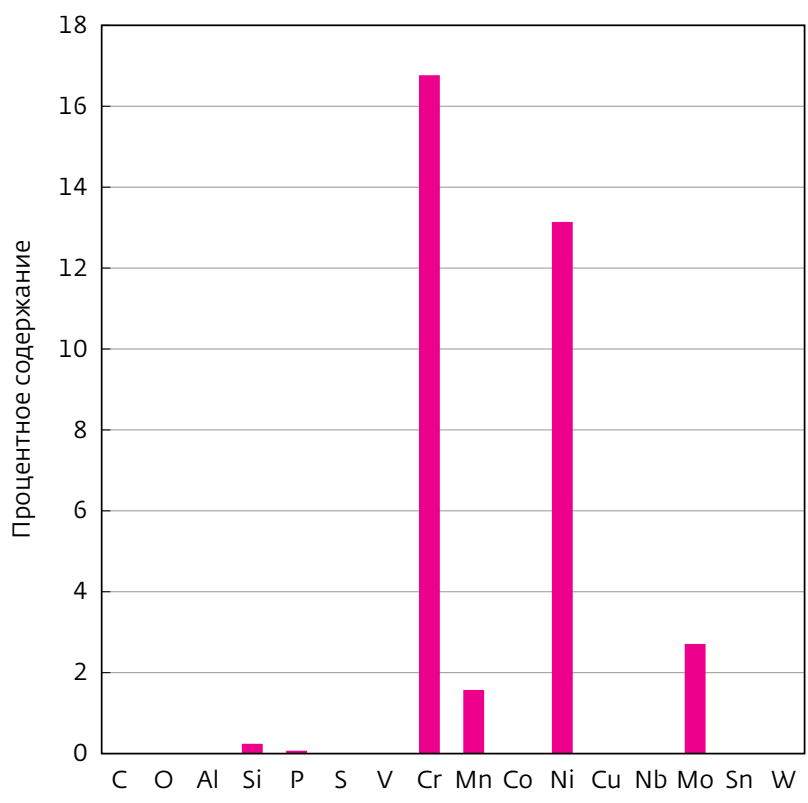

Рис.5. Состав порошка, выявленный по результатам рентгеновского контроля

Fig. 5. Content of powder detected according to results of X-ray control

ского контроля. Исходя из полученных данных, реальный состав (после контроля) и заявленный состав порошка имеют незначительные различия. Для выращивания была выбрана квадратная, специально подготовленная подложка из стали $316 \mathrm{~L}$.

Исследования проводились при помощи комплекса "СЛП-110", а также специально спроектированного лабораторного оборудования [9]; состав комплекса следующий: система перемещения подложки с возможностью нанесения слоев толщиной от 60 мкм; нож для нанесения слоев; волоконный лазер с максимальной мощностью 100 Вт; сканатор с максимальной скоростью перемещения луча $10000 \mathrm{~mm} / \mathrm{c}$, диаметром пятна в фокусе порядка 60 мкм и областью обработки 100×100 мм; камера с подачей инертного газа (аргон). На данном оборудовании был проведен ряд экспериментов по отработке формирования единичных сплавленных дорожек и замкнутых фигур (рис.6).

На рис.7 показаны результаты выращивания фигур единичного слоя со 100\%-ной плотностью. Полученные по данным экспериментального исследования параметры позволяют практически полностью избегать пористости при использовании разработанной нами установки. Однако by fine periodic structure and tiny elements existence at layers remelting. It should be noted that today hollow cellular products are produced rather easily by selective laser melting method, but parts growing having $100 \%$ density is still complicated. One of components of this problem is the supporting pieces optimum structure receiving which would guarantee a possibility of growing the dense product and its subsequent separation from supporting piece.

At MT-12 Department of Bauman Moscow State Technical University laser additive machines and technologies, including those actively developed for selective laser melting. Recently developed complex (Fig. 2) allows conducting the efficient researches of various aspects of this technology. The complex meets requirements imposed by the modern industry and is not inferior to Western counterparts.

The key diagram of selective laser melting process is shown in Fig. 3. The pressure-tight chamber filled with noble gas with a possibility of atmosphere heating includes a growing platform which has vertical movement system, and also two hoppers for powder. The powder moves from the hopper feeder by vertical movement of platform on surface. By means of a knife or a roller the necessary volume of powder is transferred to a platform for growing and is settled on it with even layer of the given thickness. Excess powder is poured to the second hopper. Further there is an impact of a laser radiation on powder, its alloy age at the first stage with a substrate, and further with the previous grown layer. As soon as the layer is grown, the growing platform with a detail goes down,

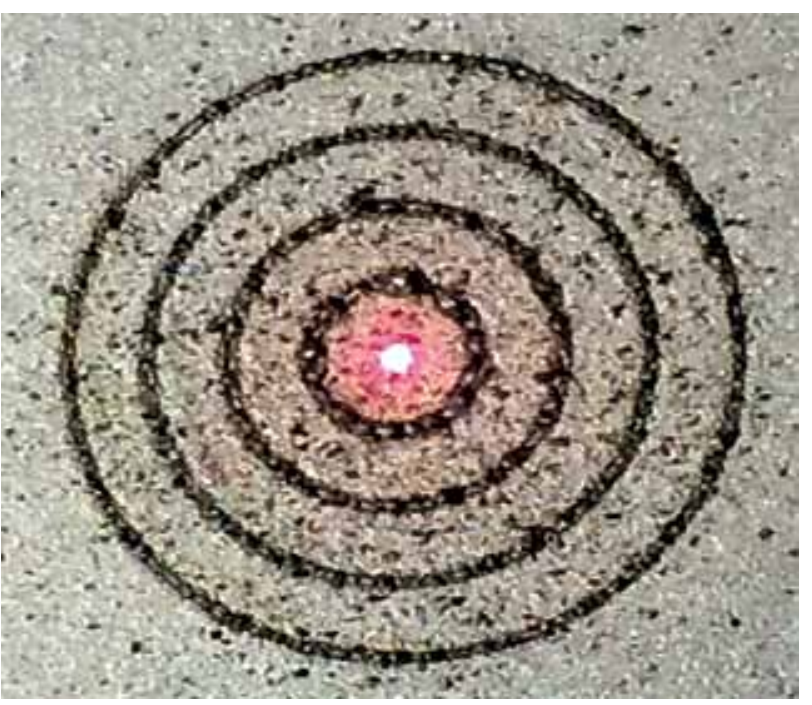

Puc.6. Пример процесса создания замкнутых фигур Fig. 6. Example of closed figure creation process 


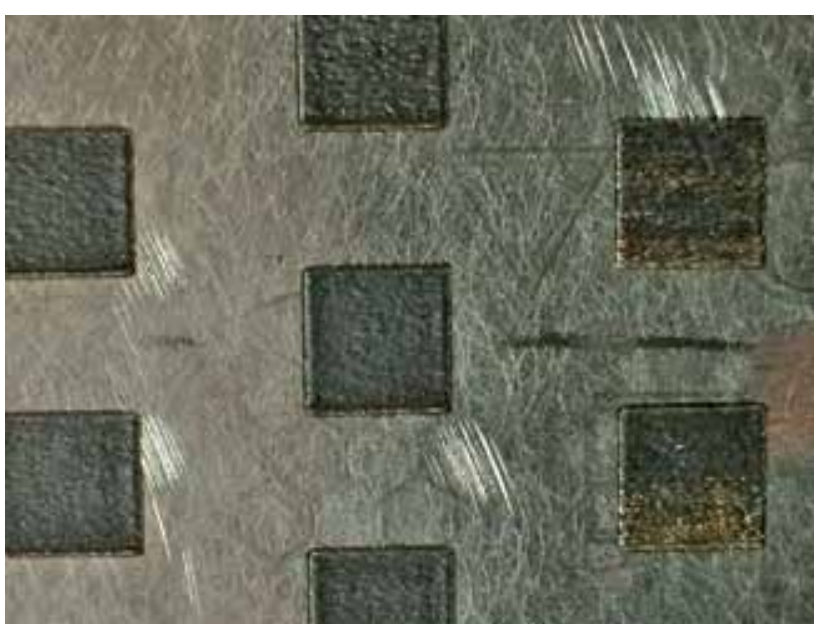

Puc.7. Единичные слои со 100\%-ной плотностью квадратной формы

Fig. 7. Square-shaped single layer with $100 \%$ density

геометрические характеристики неравномерны и сравнимы с теми, которые получают наплавкой. Снизить существенные коробления при процессе СЛП можно, уменьшив количество теплоты в зоне сплавления. Для этого необходимо отказаться от сплошной подложки и использовать сетчатые трехмерные структуры - подпорки.

Пример выращивания простых трехмерных деталей на примере тонких стенок показан на рис.8. Нам удавалось получать стабильные размеры стенок, что важно для формирования ровной геометрии будущих подпорок. Толщина стенок составила 200 мкм, а высота 5 мм с отклонением размеров не более 20 мкм, хотя присут ствовали некоторые краевые дефекты (причина которых была в несовершенстве связи системы перемещения и системы управления подачей лазерного излучения).

Для выявления мелких дефектов был проведен анализ микроструктуры образцов (рис.9). Он показал, что структура материала однородная и мелкозернистая, что соответствует классу стали. Мелкозернистая структура определяется высокой скоростью охлаждения, которая достигается при проведении процесса сЛП на опти мальных режимах. Это, согласно соотношению Холла-Петча [10], ведет к высокой твердости образ цов, которая составляет порядка 250 НВ (твер дость образцов листовой стали 316L достигает 170 НВ. Крупные поры в полученных нами образцах отсутствуют.

Полученные результаты использовались для оптимизации режимов выращивания под- and the process of new layer creation is repeated according to the same scheme.

At creation of experimental studies model and the choice of optimum conditions of carrying out selective laser melting it is very important to consider developing the process repeatability with the given accuracy [8]. All varied parameters of selective laser melting process can be divided into three basic groups $[6,7]$ :

- depending on powder characteristics,

- depending on laser radiation characteristics,

- depending on scannings strategy.

It is necessary to emphasize repeatability ensuring at products growing with tiny geometry. It is possible to provide repeatability with the right choice of modes and precise creation of supporting piece that guarantees lack of next layer distortions which can be collected and be resulted in serious defects at a large number of layers.

Researches of optimum supporting piece growing on stainless steel were conducted. Owing to high degree of alloyability and to a wide spreading in the industry the powder of stainless steel 316L is chosen for a research. Its analogues are stainless steel of 1.4429 and $03 \mathrm{H} 17 \mathrm{~N} 14 \mathrm{M} 3$ grades. The powder composition is presented in the table (globular homogeneous powder), its morphology is shown Fig. 4. The chemical composition of powder after X-ray inspection is presented in Fig. 5. Proceeding from the obtained data (after monitoring) and the declared composition of powder have slight distinctions. For growing the square, specifically prepared substrate from steel 316L was chosen.

Researches were conducted by means of the SLM 110 complex, and also specifically designed laboratory equipment [9]; the complex has the following content: system of substrate movement with a possibility of

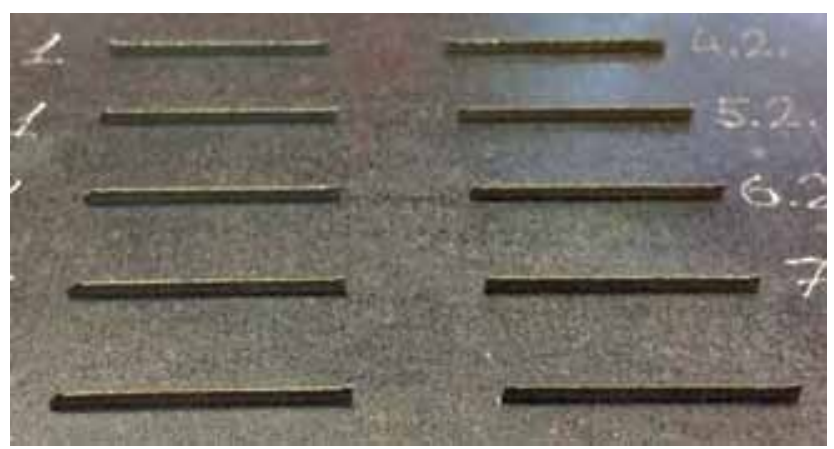

Puc.8. Пример выращенных тонких стенок

Fig. 8. Example of grown thin layers 


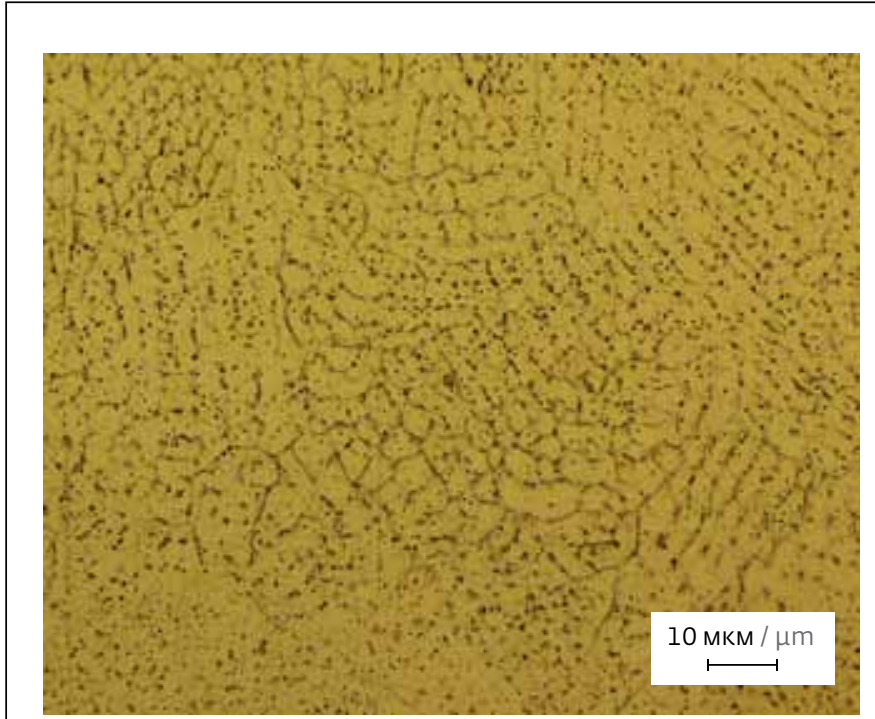

Puс.9. Микроструктура верхних слоев тонких стенок, выращенных на комплексе "СЛП-110"

Fig. 9. Microstructure of thin walls upper layers grown on SLM-710 complex

порок с трехмерной структурой. Форма подпорок должна удовлетворять ряду условий, среди которых - прочность, необходимая для надежного удержания элементов выращиваемого изделия; толщина единичного сегмента, определяющая легкость отделения подпорки; шаг между несущими элементами подпорок. Нами выращивалась серия подпорок (рис.10) со структурой, имеющей форму типа объемноцентированной кубической решетки [11]. Такая форма удобна для выращивания реальных изделий, так как способна удовлетворить вышеописанным признакам. На серии из 15 штук нами была получена достаточная повторяемость результатов без крупных дефектов.

\section{ВывОДЫ}

Применение в различных отраслях техники метода СЛП, относящегося к быстроразвивающимся аддитивным технологиям, имеет большие перспективы не только с точки зрения изготовления полых конструкций, основное применение которых находится в медицинской обла- layers drawing 60 microns thick; a knife for layers drawing; the fiber laser with the maximal power of $100 \mathrm{~W}$; a scanner with the maximum speed of beam movement of $10000 \mathrm{~mm} / \mathrm{sec}$ with spot diameter in focus of about 60 microns and processing area of $100 \times 100 \mathrm{~mm}$; the chamber with noble gas (argon) supply. A number of experiments on development of the simple alloyed paths and selfcontained figures formation were conducted on this inventory (Fig.6).

Results of growing the forms of a simple layer having $100 \%$ density are shown in Fig. 7. The parameters received according to the experimental study allow avoiding almost complete porosity when using of the installation developed by us. However geometrical characteristics are uneven and comparable with those which are received by means of weld deposit. It is possible to lower essential warpings at selective laser melting process, having reduced a heat quantity in alloyage zone. For this purpose it is necessary to refuse a continuous substrate and to use reticulate three-dimensional structures, i.e. supporting piece.

The example of simple three-dimensional parts growing on the example of thin walls is shown in Fig. 8. We managed to receive the stable walls sizes that are important for formation of supporting pieces smooth geometry. The thickness of walls is 200 microns, and the height is $5 \mathrm{~mm}$ with a dimensional defect of no more than 20 microns though there were some edge defect (the reason of which was an imperfection of movement system connection and a control system of laser radiation supply).

For identification of fine defects the analysis of sample microstructure (Fig. 9) was carried out. It showed that the structure of material is homogeneous and compact-grained that corresponds to a steel grade. The fine grained structure is defined by cooling high speed reached at carrying out the process of selective laser melting in the optimum modes. According to Hall-Petch [10], it leads to high hardness of samples which is about $250 \mathrm{BH}$ (hardness of 316L sheet steel samples reaches $170 \mathrm{BH}$. A large pores is absent in the samples received by us.

The received results were used for optimization of supporting piece growing modes with threedimensional structure. The form of supporting piece

Состав порошка стали 316L,\%

Content of steel powder $316 \mathrm{~L}, \%$

\begin{tabular}{|c|c|c|c|c|c|c|c|c|}
\hline$C$ & Si & Mn & $P$ & S & Cr & Mo & $\mathrm{Ni}$ \\
\hline$\leq 0,03$ & $\leq 0,6$ & $\leq 0,8$ & $\leq 0,02$ & $\leq 0,015$ & $15,0-17,0$ & $2,5-3,0$ & $14,0-16,0$ & $\sim 64$ \\
\hline
\end{tabular}


сти, но и с точки зрения изготовления изделий со $100 \%$-ной плотностью. Тонкостенные конструк ции, заполненные металлической сеткой с опре деленной структурой, позволяют получать легкие и достаточно прочные конструкции, но основ ные машиностроительные области, как например детали авиационной техники, требуют полностью сплошной геометрии, что встречает ряд трудностей при применении технологии СЛП. Тем не менее, правильный подход к созданию несущих подпорок - одна из составляющих успеха на этом пути. Выверенная геометрия и отсутствие пространственных погрешностей при выращивании подпорок необходимы для качественного соз дания конечной детали.

На кафедре МТ-12 мГТу им.Н.Э.Баумана активно разрабатываются лазерные аддитивные установки и технологии, в том числе для СЛП. Недавно был создан современный комплекс, удов летворяющий всем требованиям качественного проведения процесса СЛП и не уступающий иностранным аналогам. Данный комплекс использовался для отработки режимов СЛП, в том числе для выращивания подпорок. Нами были получены структуры из стального порошка с хорошими точностью и повторяемостью. При выращивании геометрии со 100\%-ной плотностью также удалось избежать серьезных дефектов.

Использование основания из тонкой сетчатой структуры при выращивании изделий методом сЛП помогает существенно снизить количество теплоты в области сплавления, что положительно сказывается на итоговом качестве получаемых изделий. Планируется проведение дальнейших работ по определению факторов, позволяющих управлять распределением тепла при СЛП, в част ности исследование переноса излучения и тепла в группе сплавляемых частиц, что позволит отработать качественную технологию получения полностью сплошных изделий методом СЛП.

\section{ЛИТЕРАТУРА}

1. Sudarshan T.S. Additive manufacturing innovations, advances, and applications.- Taylor \& Francis Croup, LLC, 2016.

2. J.-P.Kruth, V.Vandenbroucke, J.Van Vaerenberg, P.Mercelis. Benchmarking of different SLM/SLS processes as rapid manufacturing technics. - Int. Conf. Polymers and moulds innovations (PMI), Cent, Belgium, April 2005.

3. I.Gibson. Medical products for rapid prototyping: from prosthetics design to organ implant.-Additive Layered Manufacturing: From evolution to Revolution, Maribor, 2008, p.150.

4. Ader $\mathbf{C}$. and others. Research on layer manufacturing techniques at Fraunhofer.- Fraunhofer Institute for Laser Technology ILT, 4 August, 2004.

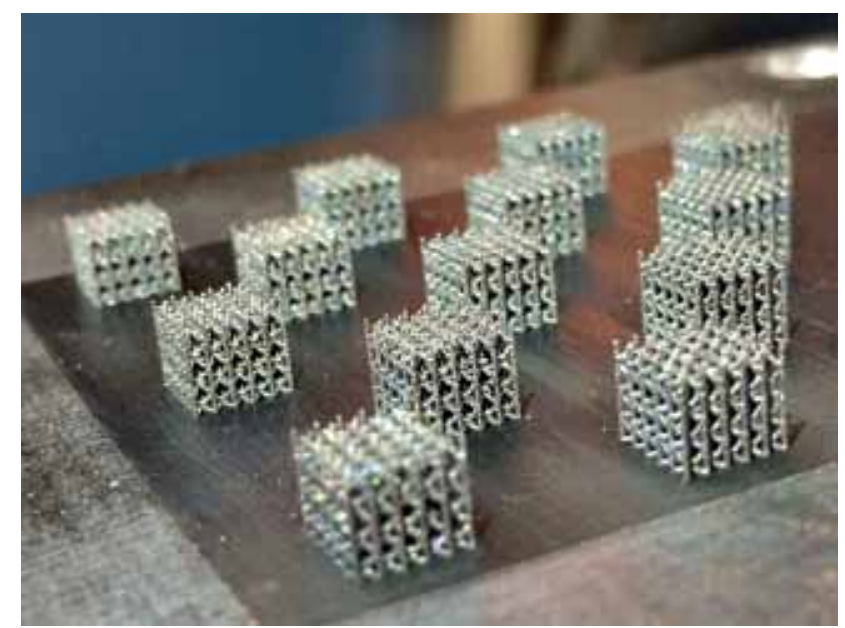

Puc.10. Подпорки из стали 316L, выращенные на комплексе "СЛП-110" при помощи метода СЛП

Fig. 10. Supporting piece of 316 L steel grown with the help of selective laser melting method on SLM-710 complex

should satisfy to a number of conditions among which there is durability necessary for reliable deduction of grown product elements; the thickness of a simple segment defining ease of supporting piece separation; a step between the bearing elements of supporting pieces. We grew up a series of supporting pieces (Fig. 10) with the structure, having body-centered cubic lattice form [11].

Such form is convenient for actual products growing as it is capable to satisfy to the above described signs. We received sufficient repeatability of results without serious defects on 15 pieces series.

\section{CONCLUSIONS}

Application of selective laser melting technology which relates to high developing additive technologies has larger perspectives not only from the point of view of hollow structures manufacture the main application of which is in medical area, but also from the point of view of products manufacture having 100\% density in various branches. The thin-walled structures filled with metal gauze with particular structure allow receiving light and rather firm structures, but the main machine-building areas, such as parts of aircraft equipment demand completely continuous geometry that meets a number of difficulties at use of selective laser melting technology. Nevertheless, the exact approach to creation of the bearing supporting piece is one of success components of this technique. The verified geometry and space errors lack at growing the supporting pieces props are necessary for highquality creation of a final part. 
5. I.Yadroitsev, I.Shishkovsky, P.Bertrand, I.Smurov. Manufacturing of fine-structured $3 \mathrm{D}$ porous filter elements by selective laser melting. - Applied Science, 2008.

6. I.Yadroitsev, Ph.Bertrand, I.Smurov. Parametric analysis of the selective laser melting process. -Applied Science, 2007, p.80648069.

7. I.Yadroitsev, L.Thivillon, Ph.Bertrand, I.Smurov. Strategy of manufacturing components with designed internal structure by selective laser melting of metallic powder. - Applied Science, 2007. p. $980-983$.

8. H.Meier, Ch.Haberland, Matwiss. U. Experimental studies on selective laser melting of metallic parts. - Werkstofftech, 2008, v. 39, № 9, p. 665-670.

9. E.Yasa, J.-P.Kruth. Microstructural investigation of Selective Laser Melting 316L stainless steel parts exposed to laser remelting. - Proc. engineering, 2011, v.19, p. 389-395.

10. Bykov A. A., Stavertij A. Ja., Kolchanov D. S. Razrabotka jeksperimental'noj ustanovki dlja izgotovlenija detalej iz metallicheskih poroshkov. Budushhee mashinostroenija. - M.: Izd-vo MGTU im. N. Je. Baumana, 2015.

11. J.P.Kruth, L.Froyen, J.Van Vaerenbergh, P.Mercelis, M.Rombouts, B.Lauwers. Selective laser melting of iron-based powder. - Journal of Materials Processing Technology, 2004, vol. 149, p. 616-622.
At MT-12 Department of Bauman Moscow State Technical University laser additive machines and technologies including selective laser melting are actively developed. Recently the modern complex which is meeting all requirements of high-quality selective laser melting process performing and not conceding to foreign analogues was created. This complex was used for selective laser melting modes development including supporting pieces growing. We received the structures of steel powder with a good accuracy and repeatability. At geometry growing of $100 \%$ density also it was succeeded to avoid serious defects.

The use of the basis of fine reticulate structure at growing of products by selective laser melting method helps to lower significantly a quantity of heat in alloyage area that positively affects the total quality of the received products. Further carrying out further works on definition of the factors allowing operating distribution of heat at selective laser melting, in particular a research of transfer of radiation and heat in alloyed particles group that should allow to fulfil the qualitative technology of receiving completely continued products by selective laser melting method is planned. 